\title{
Definiteness, Structure and Agreement in Turkish Possessives
}

\author{
Betul Erbasi*
}

\begin{abstract}
The present study argues for different levels of definiteness in the nominal domain based on an analysis of two different kinds of possession phrases in Turkish. In line with related research (e.g. Campbell 1996, Haegeman \& Ürögdi 2010 and Jimenez-Fernandez 2012, Zamparelli 2014), I argue that the more definite a possession phrase is in Turkish, the more structure it has. This extra structure also hosts a definiteness operator, which accounts for island-like properties of the more definite possession structures. The proposal can therefore account for interpretational and syntactic properties of different possession structures in Turkish. I also argue that agreement properties are also accounted for with this proposal, when coupled with the island-forming properties of agreement in Turkish (George \& Kornfilt 1981). The current proposal then contributes to previous research on levels of definiteness and it does so by focusing on a type of determiner phrases that previous research on levels of definiteness did not focus on.
\end{abstract}

Keywords. possession, definiteness, referentiality, specificity, agreement, islandhood, Turkish

1. Introduction. Definiteness in nominal structures has been defined in various ways. For Russel (1905), a definite entity refers to a unique one whereas for Heim (1982), it refers to a familiar one. Uniqueness entails that there is one entity in the world that matches the description by the noun and familiarity entails that the entity is known by the speaker and the hearer either through linguistic introduction (strong familiarity in Roberts 2003) or through extra-linguistic factors such as contextual salience (weak familiarity in Roberts 2003). Structurally, definiteness is associated with the DP layer. A definite noun is taken to be a DPand a noun that is not marked for definiteness (i.e. generic) is an NP.

Recently, however, there has been research showing that the distinction between definiteness and indefiniteness is not so clear-cut. For example, there are nouns that are indefinite, which are neither definite nor generic. The distinction between definite and indefinite nouns has been shown to be structurally important in that definite noun phrases are more islandlike, as opposed to indefinite noun phrases (Fiengo \& Higginbotham 1981, Diesing 1992, Bošković 2008, Haegeman \& Ürögdi 2010 and Jimenez-Fernandez 2012).

Another way the notion of definiteness is not so clear-cut is different layers of definiteness. For instance, there is a difference between the more definite/stronger determiners versus weaker ones such that the former is generated higher structurally (Zamparelli 2014).

This paper will discuss data from Turkish and show that there are different definite noun phrases: strongest ones and weaker ones. Only the latter is compatible with elements indicating indefiniteness and only the former has (strong) island properties. These two definite noun

\footnotetext{
* I owe many thanks to Maria Luisa Zubizarreta, Roumyana Pancheva, Audrey Li, Stefan Keine, Maria Polinsky and Songül Gündoğdu for their very valuable feedback. All errors are mine. Author: Betul Erbasi, University of Southern California (erbasi@usc.edu).
} 
phrases are exemplified in (1a) and (1b), respectively, followed by a generic, bare noun phrase in (1c): ${ }^{1}$
a. çocuğ-un kitab-1
'the book of the child'
b. çocuğ-un kitap
child-3SGEN book
'the book of the child'
c. kitap
book

Genitive Phrase (GP)

Agreement-Free Genitive Phrase (AFG)

\section{Bare Noun}

Bare nouns as in (1c) have a generic meaning, which English does not have. Therefore, it is not $a$ book but just book. These nouns will be important to establish a contrast between (1a)-(1b) on the one hand and (1c) on the other. But I will leave it at that for now and discuss the two possession phrases.

The most immediately visible difference between the two types of possession phrases in (1a) and (1b) is in agreement: GPs have the agreement on the head noun (rightmost noun) whereas AFGs do not.

AFGs are considered as the colloquial version of GPs (Göksel \& Kerslake 2005; Kunduracı 2013). However, experimental data indicate that young people use this structure comfortably, and in fact some prefer AFGs over GPs (Erbasi \& Kaiser 2018). Öztürk \& Taylan (2016) also pointed out that there might be more systematic differences between the two than pure colloquialism. Therefore, it is vital that the difference between the two structures not be reduced to mere colloquialism. This paper will provide further support to the suggestion that the difference between the two possession phrases are not mere colloquialism. The systematic differences are given in (2) and the proposal in (3) will be posited in order to account for the points in (2):

(2) a. GPs have agreement on the head noun whereas AFGs do not.

b. GPs do not necessarily require familiarity or uniqueness whereas AFGs do.

c. GPs allow extraction of their parts whereas AFGs do not.

d. GPs allow question words in them whereas AFGs do not.

(3) GPs have only one layer of $\mathrm{DP}\left(\mathrm{DP}_{1}\right)$, one which is used to assign genitive case, whereas AFGs have another layer of DP $\left(\mathrm{DP}_{2}\right)$ in addition to $\mathrm{DP}_{1}$, hosting an OP in its Spec.

2. Data. In this section, I will introduce the data relevant to my proposal. The first part will be data showing that both GPs and AFGs are DPs. To this end, I will compare them to bare nouns, which are NPs. This will establish a basic syntactic similarity between GPs and AFGs.

Both GPs and AFGs must be accusative-marked (4) whereas bare nouns are marked with it only if they are specific (accusative marks specificity in Turkish (von Heusinger \& Kornfilt 2005) (compare (5) and (6)):

\footnotetext{
${ }^{1}$ Abbreviations are: ABL: Ablative, ACC: Accusative, AOR: Aorist, CAUS: Causative, COND: Conditional, DAT: Dative, FUT: Future, GEN: Genitive, IMPF: Imperfective/Progressive, INDIRPST: Indirect/Reported Past, INST: Instrumental, LOC: Locative, NEG: Negation, PASS: Passive, PL: Plural, PST: Past, S: Singular; $3: 3^{\text {rd }}$ person. Capital letters in affix glosses indicate sounds that undergo harmony.
} 

a. Çocuğ-un kitab-1-*(n1) ${ }^{2} \quad$ oku-du-m
child-3SGEN book-3S-*(ACC) read-PST-1S
'I read the child's book'
b. Çocuğ-un kitab-*(1) oku-du-m
child-3SGEN book-*(ACC) read-PST-1S
'I read the child's book'
AFG
a. Bugün kitap oku-du-m
today book read-PST-1S
'I did book-reading today'
b. Bugün kitab-1 oku-du-m today book-ACC read-PST-1S
'I read the book today'

\section{Bare Noun}
Bare Noun

(5)

In addition, GPs and AFGs do not appear immediately adjacent to the verb if there is a lowerlevel adverb (e.g. yavaş 'slowly') in neutral contexts. Therefore, they cannot be pseudoincorporated to the verb, as shown in (6). Bare nouns, on the other hand, undergo pseudoincorporation with the verb in Turkish (Öztürk 2005, following Massam 2001; Arslan-Kechriotis 2006). Therefore, a bare object cannot be scrambled away from the verb as shown in (7b):
a. Çocuğ-un
kitab-1-n1
child-3SGEN book-3S-ACC slow
yavaş
oku-du-m
GP
read-PST-1S
'I read the child's book slowly'
b. *Yavaş çocuğ-un kitab-1-nı slow child-3SGEN book-3S-ACC
'I read the child's book right away'
oku-du-m
read-PST-1S
c. Çocuğ-un kitab-1 hemen oku-du-m child-3SGEN book-ACC slow read-PST-1S
'I read the child's book slowly'
d. *Yavaş çocuğ-un kitab-1 oku-du-m slow child-3SGEN book-ACC read-PST-1S 'I read the child's book slowly'
a. Ali yavaş kitap oku-du
Ali slow book read-PST
'Ali did book-reading slowly'
b. *Ali kitap yavaş okudu

Bare Noun

The test on accusative points out to a definite/specific reading of GPs and AFGs and a generic (non-definite/non-specific) reading of bare nouns (unless accusative-marked), as Turkish accusative indicates specificity (von Heusinger \& Kornfilt 2005) (I will discuss the role of accusative for definiteness later). Definiteness/specificity is a property of DPs, therefore, GPs and AFGs are DPs. Pseudo-incorporation is also possible with NPs (Massam 2001), therefore,

\footnotetext{
${ }^{2}$ Accusative marking in Turkish is subject to phonological changes. It is $-\mathrm{nI}$ if it attaches to a vowel-ending stem and $-\mathrm{I}$ if it attaches to a consonant-ending stem. The vowel also undergoes vowel harmony and have four variants. Therefore, accusative marker has eight shapes in Turkish: -1, -i, -u, -ü, -n1, -ni, -nu, -nü.
} 
the inability of GPs and AFGs to do so confirm the conclusion from the accusative test. ${ }^{3}$ Thus, overall, GPs and AFGs are DPs while bare nouns are NPs.

That is not to say that GPs and AFGs do not exhibit differences, though, as they have interpretational and syntactic differences. Starting with interpretational differences, there is evidence that AFGs are 'more definite' than GPs, where a definite noun is one that is familiar (Heim 1982) and unique (Russel 1905). Context 1 in example (8) shows that both GPs and AFGs are good in a context where both the speaker and the hearer are familiar with the given entity (the part indicating familiarity is bolded in context). The hearer is not familiar with the entity in Context 2, as indicated with the bolded part, and AFGs are degraded or unacceptable in this case whereas GPs are good. Familiarity here includes weak familiarity (i.e. non-linguistic familiarity, Roberts 2003):

(8) Context 1 (common ground): You are at a picnic with your neighbors when everyone present in the picnic sees a boy crying next to his bike. You help the boy and come back. Your neighbors ask 'What happened?'. You say:
a. (Bir şey yok.) Çocuğ-un bisiklet-i bozul-muş
'Nothing. The child's bike was broken'
(Nothing) child-3GEN bike-3S break-INDPST
b. (Bir şey yok.) Çocuğ-un bisiklet-i bozul-muş
(Nothing) child-3GEN bike-3S break-INDPST
'Nothing. The child's bike was broken'
GP
AFG

Context 2 (Hearer doesn't know about the entity): Your neighbors are sitting in the picnic area, where you are walking to join them. On your way, when your neighbors still cannot see you, you see a boy crying next to his bike and help him. You call your neighbors and tell them you helped a child (without specifying with what). When you arrive, your neighbors ask what happened and you say:
a. (Bir şey yok.) Çocuğ-un bisiklet-i bozul-muş
(Nothing) child-3GEN bike-3S break-INDPST
'Nothing. The child's bike was broken'
b. ?/\#(Bir şey yok.) Çocuğ-un bisiklet-i bozul-muş
(Nothing) child-3GEN bike-3S break-INDPST
'Nothing. The child's bike was broken'

Another piece of evidence that AFGs need to refer to familiar entities is that they do not allow indefinites, as indefinites indicate lack of knowledge on the part of the hearer:
a. Çocuğ-un bir kitab-1-nı bul-du-m child-3SGEN one book-3S-ACC find-PST-1S
'I found a book of the child'
b. Bir çocuğ-un bir kitab-1-nı bul-du-m one child-3SGEN one book-3S-ACC find-PST-1S 'I found a book of a child'
c. Bir çocuğ-un kitab-1-nı bul-du-m one child-3SGEN book-3S-ACC find-PST-1S 'I found the book of a child'

\footnotetext{
${ }^{3}$ As pointed out by an anonymous reviewer, there are other tests such as referring back to the noun: this is possible with GPs and AFGs but not with bare nouns. That and other tests support the division made here.
} 

a. *Çocuğ-un bir kitab-1 bul-du-m child-3SGEN one book-ACC find-PST-1S
'I found a book of the child'
b. *Bir çocuğ-un bir kitab-1 bul-du-m one child-3SGEN one book-ACC find-PST-1S 'I found a book of a child'
c. *Bir çocuğ-un kitab-1 bul-du-m one child-3SGEN book-ACC find-PST-1S 'I found the book of a child'

In addition to familiarity, AFGs also require uniqueness, whereas GPs may or may not (Öztürk et al. 2015). As shown in (11), AFGs are worse than GPs in non-unique contexts (Context 2), though neither is perfect: ${ }^{4}$

(11) Context 1 (unique): Ali, who works in Osman's yard, and I are having a conversation about his day of working in the yard. (I know that there is exactly one tree in Osman's yard.) (Adapted from Schwarz 2009)
a. Osman-1n ağaç-1n- bir kuş kon-du
Osman-3SGEN tree-3S-DAT one bird hang-PST
GP
'A bird sat on Osman's tree'
b. Osman-ın ağaç-a bir kuş kon-du
'A bird sat on Osman's tree'
Osman-3SGEN tree-DAT one bird hang-PST

Context 2 (Non-Unique): Same as above, but there are two trees
a. ?Osman-1n ağaç-1n-a bir kuş kon-du
Osman-3SGEN tree-3S-DAT one bird hang-PST
'A bird sat on Osman's tree'
b. \#Osman-in ağaç-a bir kuş kon-du
Osman-3SGEN tree-DAT one bird hang-PST
'A bird sat on Osman's tree'

Another piece of evidence for the uniqueness requirement by AFGs is that they do not allow a quantifier possessor or possessee:
a. Her araba-nın direksiyon-u bozuk-tu every car-3SGEN steering.wheel-3S broken-PST 'The steering wheel of every car was broken'
b. \#Her araba-nın direksiyon bozuk-tu every car-3SGEN steering.wheel broken-PST 'The steering wheel of every car was broken'
cf. Araba-nin direksiyon bozuk-tu
GP

(13) In a world where cars have multiple steering wheels:
a. Araba-nın her direksiyon-u bozuk-tu car-3SGEN every steering.wheel-3S broken-PST 'Every steering wheel of car was broken'

\footnotetext{
${ }^{4}$ Note that the contrast in (11) is not very strong (though still available) but (12) and (13) will support the pattern.
} 

b. \#Araba-nın her direksiyon bozuk-tu car-3SGEN every steering.wheel broken-PST
'Every steering wheel of car was broken'

cf. Araba-nin direksiyon bozuk-tu

AFG

As for structural differences between the two, (14) and (15) show that GPs allow extraction of their parts (14) while AFGs do not (15):
a. Bak, bebeğ-in $n_{i}$ bul-un-du
find-PASS-PST
$\mathrm{t}_{\mathrm{i}}$ araba-s1 (Telaş yapma)
GP
look baby-3SGEN
car-3S (Don't panic)
'Look, the toy car of the baby has been found (Don't panic)'

b. Bak, arabası $1_{i}$ bulundu bebeğin $t_{i}$ (Telaş yapma)

Base Order: Bebeğin arabası bulundu
a. *Bak, bebeğ-in $n_{i}$ bul-un-du
look, baby-3SGEN find-PASS-PST
$t_{i}$ araba (Telaş yapma)
car (Don't panic)
'Intended: Look, the toy car of the baby has been found (Don't panic)'
b. *Bak, araba $a_{i}$ bulundu bebeğin $t_{i}$ (Telaş yapma)
Base Order: Bebeğin araba bulundu

GPs also allow question words in them (16) whereas AFGs do not (17), except in echo questions (Turkish is a wh-in situ language):
a. Çocuğ-un
ne-si-ni
bul-du-n
child-3SGEN
what-3S-ACC
find-PST-2S
'What that belongs to the child did you find?'
b. Kim-in kitab-1-n1 oku-du-n?
who-3SGEN book-3S-ACC read-PST-2S
'Whose book did you read?'

GP
a. *Çocuğ-un ne-yi bul-du-n child-3SGEN what-ACC find-PST-2S 'Intended: What that belongs to the child did you find?'
b. *Kim-in kitab-1 oku-du-n? who-3SGEN book-ACC read-PST-2S 'Intended: Whose book did you read?'

The main points made in this section are summarized in (18):
a. Bare nouns are NPs while GPs and AFGs are DPs.
b. AFGs require familiarity and uniqueness while GPs do not.
c. AFGs do not allow extraction of their parts while GPs do.
d. Parts of AFGs cannot be questioned while those of GPs can.

The proposal to follow will account for these properties as well as the agreement difference mentioned before. 
3. Proposal. I propose the following structures for GPs and AFGs, respectively. I take bare nouns to be simple NPs: ${ }^{5}$

a. GP

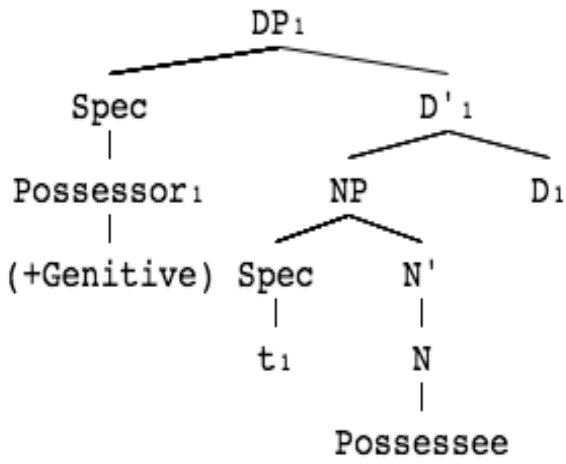

b. AFG

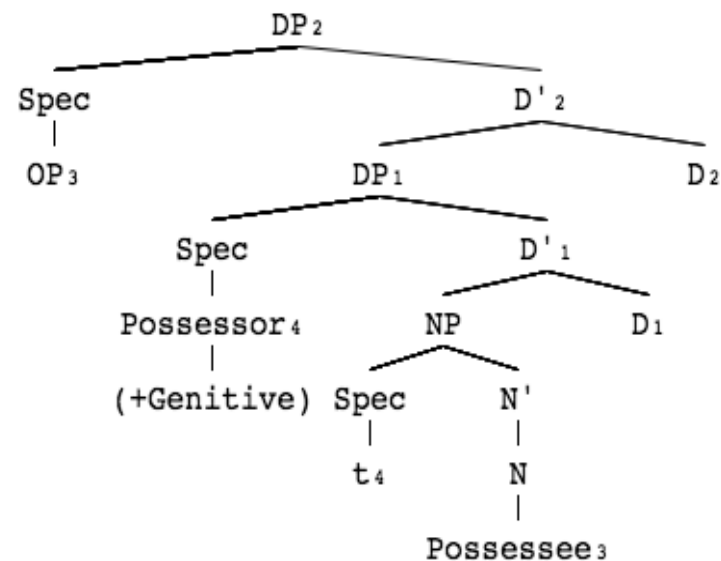

Both GPs and AFGs are DPs because they both have $\mathrm{DP}_{1}$, the first layer of the DP-domain, as the data where they were contrasted with bare nouns showed. $\mathrm{DP}_{1}$ is the layer that assigns genitive case to the possessor à la von Heusinger \& Kornfilt (2005), explaining how both GPs and AFGs have genitive case on their possessor. The possessor is base-generated in SpecNP and

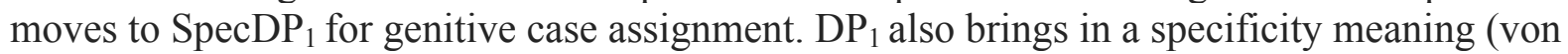
Heusinger \& Kornfilt 2005), as genitive case is associated with specificity in Turkish. This accounts for the accusative-case requirement of these structures. This also accounts for why GPs can host indefinites: Because $\mathrm{DP}_{1}$ indicates specificity, specifics can be indefinite. A similar explanation goes for how they can adapt to co-variation as well. In the case of AFGs, the properties of $\mathrm{DP}_{2}$ overrides $\mathrm{DP}_{1}$.

What AFGs additionally have is $\mathrm{DP}_{2}$, embedding $\mathrm{DP}_{1}$. $\mathrm{DP}_{2}$ hosts a definiteness operator, $\mathrm{OP}$, in its Spec. ${ }^{6}$ Recall that AFGs need to refer to familiar and unique entities that are known by the speaker and the hearer whereas default possession phrases need not (though they may). OP achieves this effect. Adapting the proposal in Campbell (1996), I argue that this operator serves to link the head noun to a discourse referent. That is, there is a definite (familiar, unique) discourse referent that the head noun refers to and OP links the two via co-referentiality. The linking can be represented as in (20):

$$
\left[\mathrm{DP}_{2} \mathrm{OP}_{\mathrm{i}}\left[\mathrm{DP}_{1} \text { [Possessor] [[NP Possessee } \mathrm{i}\right] \mathrm{D}^{\prime}\right]
$$

In the next section, I will discuss the details of the proposal and how it accounts for the patterns posited in Section 2.

\footnotetext{
${ }^{5}$ A reviewer suggests that there could be multiple specifiers of the same DP. However, this does not seem to be good for Turkish. There is evidence that SpecDP is where genitive case is assigned (von Heusinger \& Kornfilt 2005) and multiple genitive assignment is not possible in the language (also see example (31)). In my account, $\mathrm{DP}_{1}$ assigns genitive case and other DP-related functions such as definiteness are in $\mathrm{DP}_{2}$. The reviewer also suggests that we may use a strong and weak DP. However, in such an account, we fail to account for why a strong DP would prevent overt agreement would not find an explanation whereas in mine there is a suggestive direction.

${ }^{6}$ Note that in my account, having a DP does not necessarily bring in definiteness, as in the case of GPs.
} 
4. Analysis \& Discussion. The proposal in (19) indicates that there is an operator in $\mathrm{SpecDP}_{2}$. This proposal draws on ideas from Zamparelli (2014), who argue that more definite DPs have more structure, and Haegeman \& Ürögdi (2010), who argue that referential DPs have an operator movement chain, which results in the operator landing in the Spec position of the highest projection in the DP domain. For them, this movement in DPs is one of the parallelism points to clausal domain (D for DP and C for CP in (20)). Their representation of the process is in (21) (p. 147):

$$
\left[\mathrm{RDP} / \mathrm{RCP} \mathrm{Op}_{\mathrm{i}} \mathrm{Sub}_{(\mathrm{D} / \mathrm{C})} \ldots\left[\mathrm{FP}_{\mathrm{i}}[\mathrm{NP} / \mathrm{TP} \mathrm{N} / \mathrm{T} \ldots]\right]\right]
$$

The operator chain in (21) is one "between a functional projection dominating the contentful part of the phrase (an extended projection of $\mathrm{N}$ in the case of DP, and the event in the case of a clause) and the left edge of the topic field of the referential phrase (Haegeman \& Ürögdi, 2010: 147". The Op is a specificity operator, or a kind of DP-internal topic, in Haegeman \& Ürögdi (2010), who base this suggestion on Campbell (1996). This latter study argued that referentiality in DPs is due to an operator chain between SpecDP and the subject of the small clause formed by the predicate NP. A representation for Campbell's proposal is given in (22) (Haegeman \& Ürögdi 2010, p. 146). In Campbell's proposal, this operator serves to link the internal subject position to a discourse referent. My proposal in (19) and the representation in (20) draws on Campbell's proposal:

\section{$[\mathrm{DP}$ OP $[$ the $[\mathrm{sc}[\mathrm{e}]$ thief]}

My proposal is similar Campbell (1996) in another way. Recall that AFGs require familiarity and uniqueness, hence they are definite (=referential in Campbell's terms). Thus, similar to Campbell's proposal, the OP in my proposal stands in for a definite/referential entity in discourse and links it to the DP head (i.e. the possessee).

One way my proposal differs from Campbell (1996) and Haegeman \& Ürögdi (2010) is that I do not assume movement but I assume a coreferentiality link between the OP and the DP head. The reason for this is that the referential/definite entity is the possessee itself and possessee is in a head position whereas OP is in Spec (head-movement constraint, Travis 1988).

The operator account can also account for the syntactic and morphological differences between the two structures. I start with syntactic differences.

Recall that GPs allow extraction of their parts whereas AFGs do not and GPs allow whwords in them whereas AFGs do not. I argue, following various works on referentiality level in DPs and islandhood, that the more definite DPs cause island-like effects. In the present case, this means that AFGs are (strong) islands due to the existence of the extra DP layer, whose Spec is filled with OP. Thus, the escape hatch of the DP domain is filled, preventing extraction and external probes cannot probe into the DP either. This is similar to accounts in Jimenez-Fernandez (2012) and Zamparelli (2014) (among others), which I briefly review below.

Jiménez-Fernández (2012) suggested that definite DPs are islands as opposed to indefinite DPs in various languages. The following are his examples from Spanish. A definite DP such as los empleados de AENA 'the employees of AENA' does not allow sub-extraction (degraded or ungrammatical) while an indefinite DP such as varios empleados de AENA 'several employees of AENA' does:

a. ??De $\mathrm{AENA}_{\mathrm{i}}$ han interrumpido el tranajo [los empleados $t_{i}$, no de Iberia of AENA have-PERF.3PL interrupted the work the emplyees not of Iberia 'AENA employees have interrupted their work, not Iberia employees' 
b. De $A E N A_{i}$ han interrumpido el tranajo [varios empleados $t_{i}$ ], no de Iberia of AENA have-PERF.3PL interrupted the work several emplyees not of Iberia 'Several AENA employees have interrupted their work, not Iberia employees'

The main proposal in Jiménez-Fernández (2012) is that definite DPs are generated higher. This causes them to be phases (islands) as opposed to indefinite DPs. In fact, he states that "DPs are phases (hence D*Ps) when certain LF-related properties intersect. If a DP is a phase it blocks subextraction (p. 8)". Jiménez-Fernández (2012) shows that definiteness is a factor causing islandhood. However, he does not make a distinction in levels of definiteness, which is the distinction in my data. Zamparelli (2014) helps just in this aspect, as this proposal is specifically based on levels of definiteness. According to this proposal, the more definite an element is, the higher it is generated and the highest (i.e. the most definite) element causes islandhood. Therefore, he argues for a multilayered DP approach, given in (24):

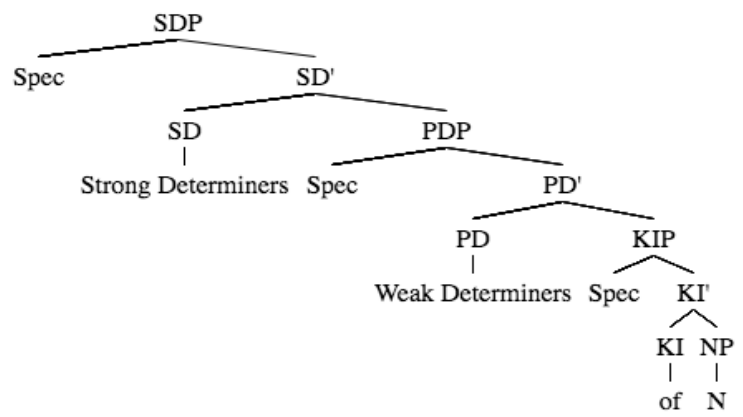

The topmost layer in the DP is SPD, reserved for strong determiners (e.g. every). Then comes the predicative DP (PDP) for weak determiners (e.g. cardinal numbers). PDP is followed by Kind DP (KIP), whose head is filled with of in English. If the outermost layer is filled (SpecSDP), say by every, extraction is not possible. For example, if there is a strong determiner present, the Italian kind marker ne cannot be raised. That is, the element in KIP in (24) cannot be raised crossing over the SDP, if SDP is filled. Therefore, SDP is the landing site for further movement. Below is the relevant example from Zamparelli (2014: 145), followed by the relevant proposal:

$$
\begin{aligned}
& \mathrm{Ne}_{\mathrm{i}} \quad \text { conosco }\left[\mathrm{SDP}\left({ }^{*} \mathrm{i}\right)\left[\mathrm{PDP} \text { molti } t_{i}\right]\right] \\
& \text { of.them I.know (the) many } t]
\end{aligned}
$$

(26) The specifiers of a lexically filled $\mathrm{SD}^{\max }$ cannot be used as an (intermediate) landing site.

In my data, the strong determiner corresponds to $\mathrm{OP}$ and weaker determiner corresponds to $\mathrm{DP}_{1}$ elements (i.e. the genitive-marked possessor).

The last property I will talk about now is the agreement pattern. Agreement in possession phrases in Turkish happens with the non-head (possessor) noun:
a. ben-im araba-m
I -1SGEN car-1S
'my car'
b. sen-in araba-n
you-2SGEN car-2S
'your car'
s/he-3SGEN car-3S
'his/her car'
c. o-nun araba-s1 
Agreement is always the last element in the nominal domain, suggesting that it happens in the highest phrase level in Turkish, if any agreement will take place. Thus, the highest phrase in the nominal domain has to agree. This is also related to the fact that it has been known to form inaccessible, island-like structures in Turkish, thus sealing off a domain turning it into an island (George \& Kornfilt 1981). For example, binding is not possible into a direct clausal complement with agreement (28a), as opposed to one without (28b) (George \& Kornfilt 1981, p. 119). In (28a), the matrix subject biz 'we' can bind into the ECM-marked embedded reciprocal subject birbirimiz '(our) each other'. This is not the case in (28b):
a. $\left(\right.$ biz $\left._{\mathrm{i}}\right)\left[\right.$ birbir-imiz $\mathrm{i}_{\mathrm{i}} \mathrm{i}$
viski-yi
iç-ti]
san-1yor-uz
we each.other-1PLPOSS-ACC
whisky-ACC
drink-PST
believe-IMPF-IPL
'We believe each other to have drunk the whisky'
b. *(bizi $)$ [birbir-imizi $\mathrm{b}_{\mathrm{i}}$ viski-yi iç-ti-k] san-1yor-uz we each.other-1PLPOSS-ACC whisky-ACC drink-PST-1PL believe-IMPF-IPL 'We believe each other to have drunk the whisky'

In GPs, agreement happens because the possessor, the element triggering the agreement happens to be in the highest phrase level and satisfies the agreement feature (19a). In AFGs, on the other hand, the element occupying the highest level is PRO, standing in for the head noun. The agreement with that elements happens and is presumably null. This account of agreement is speculative, which is why it was questioned by an anonymous reviewer, and future research will show if it is on the right track. The question of why agreement is banned in $\mathrm{DP}_{1}$ in AFGs needs further research, though the language seems to provide evidence for a highest-phrase preference for agreement.

This completes the discussion of the properties differentiating the two possession structures in Turkish. These are given in (29):

(29) a. GPs have agreement on head noun whereas AFGs do not.

b. GPs do not necessarily require familiarity or uniqueness whereas AFGs do.

c. GPs allow extraction of their parts whereas AFGs do not.

d. GPs allow question words in them whereas AFGs do not.

As a last point in this section, I will address previous research comparing GPs and AFGs. Öztürk \& Taylan (2016) is the most systematic one and they proposed the structures in (30) to represent GPs and AFGs, respectively:

a. GP

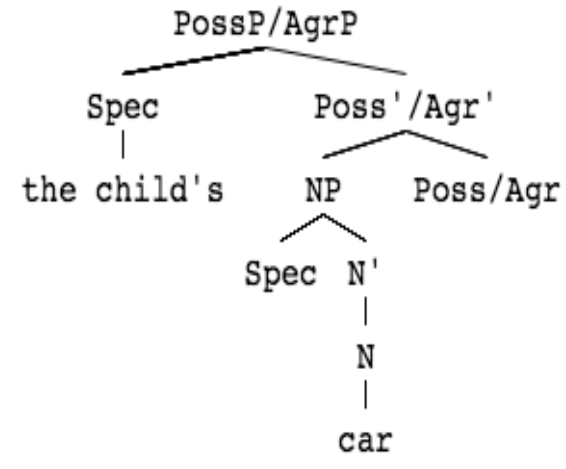

b. AFG

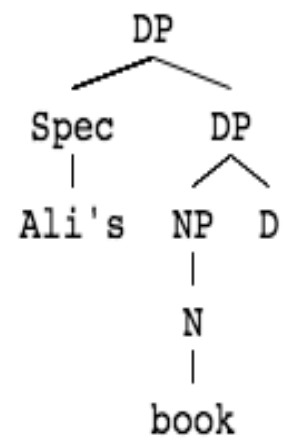

GPs have a PossP/AgrP, where agreement takes place. AFGs have a DP and the possessor in them is an adjunct. Therefore, AFGs are single head nouns modified by the possessor. 
One of the reasons I do not adopt their analysis is that their proposal is based on a restricted set of data, as they argue that AFGs are good only with body part (e.g. child's nose), autonomous part (e.g. the car's tire), agentive (e.g. child's poem) and control (e.g. the woman's car) head nouns. But they are not good with inherently relational nouns (e.g. the teacher's aunt). However, most Turkish speakers I consulted accept AFGs with any kind of nouns. Therefore, I believe that the data set in Öztürk \& Taylan to be incomplete, which makes their proposal questionable. My proposal does not depend on noun type, therefore, it can encompass all types of nouns.

There is also another, indirect and tentative reason not to adopt their analysis. Öztürk \& Taylan's analysis takes the possessor to be an argument in GPs and a modifier in AFGs. However, there is indirect evidence that the possessor in AFGs are not modifiers. (31) shows that AFGs do not allow more than one adjectival modifier easily. This is unlike regular modifiers, which are infinitely recursive (30a). In other words, if possessors were modifiers, why would they behave differently from other modifiers in that they are non-recursive:
a. Genç akıllı uzun ... doktor young smart tall doctor
'the young, smart and tall doctor'
b. Kadın-1n doktor woman-3GEN doctor 'the woman's doctor'
c. *Kadın-1n adam-ın doktor woman-3GEN man-3GEN doctor '*the woman's the man's doctor'
AFG
AFG

5. Conclusion. Based on two different kinds of possession phrases in Turkish, a structure that has not been focused on much in the layers of DP literature, I proposed that there are different layers of definiteness, reflected in the structure of DP. The more definite elements are situated in higher projections in the DP, making more definite noun phrases have a bigger structure and causing island-like effects. This proposal is a contribution to the multiple layers approach to the DP. That is, I suggest that there are different definiteness levels and this is represented in the syntactic structures of different kinds of DPs. This, therefore, supports proposals as in Campbell (1996), Zamparelli (2014), and in parts Haegeman \& Ürögdi (2010) and Jimenez-Fernandez (2012). My proposal has a different contribution in not only that it brings in data supporting these studies from a different language from a different language family (although JimenezFernandez mentions a different set of Turkish data but it also looks into a different type of DP. The above-mentioned studies focused definite noun phrases. By focusing on possession structures, I show that what has been said for a kind of determiner phrase (i.e. definite noun phrase) can be extended to other kinds as well.

A lot of data points are left for future research. For example, although wh- words are not good in AFGs, D-linked wh- words seem to be better:
a. Çocuğ-un hangi kitab-1 bul-du-n
child-3SGEN which book-ACC find-PST-2S
'Which book that belongs to the child did you find?'
b. Hangi çocuğ-un kitab-1 oku-du-n? which child-3SGEN book-ACC read-PST-2S 'Which child's book did you read?'


Given that OP is heavily contextually dependent in that I take OP to be an element that links the internal subject position to a discourse referent, following Campbell (1996), a proposal along the lines of feature matching between context dependent OP and context-dependent D-linked whwords seems likely. Future research should look into the possibility of this idea.

\section{References}

Abney, Steven. P. 1987. The English noun phrase in its sentential aspect. PhD Dissertation, MIT.

Arslan-Kechriotis, Z. Ceyda. (2006). Case as an uninterpretable feature. Unpublished PhD Dissertation, Istanbul: Bogaziçi University.

Bošković, Željko. (2008). What will you have, DP or NP?. In Proceedings of NELS 37, p. 101.

Campbell, Richard. 1996. Specificity operators in SpecDP. Studia Linguistica, 50(2), 161-188.

Erbasi, Betul., Kaiser, Elsi. 2018. Familiarity and personal experience effects on possessive structures, $2^{\text {nd }}$ California Meeting on Psycholinguistics.

Fiengo, Robert. \& Higginbotham, James. 1981. Opacity in NP. Linguistic Analysis Seattle, Wash., 7(4), 395-421.

George, Leland. \& Kornfilt, Jaklin. 1981. Finiteness and boundedness in Turkish. Binding and filtering, 105, 127.

Göksel, Asl1. \& Kerslake, Celia. 2005. Turkish: A Comprehensive Grammar. London:Routledge.

Haegeman, Liliane. \& Ürögdi, Barbara. 2010. Referential CPs and DPs: An operator movement account. Theoretical linguistics, 36(2-3), 111-152.

Heim, Irene. 1982. The semantics of definite and indefinite noun phrases. Garland Publishers: New York, 1988.

Kundurac1, Aysun. 2013. Turkish noun-noun compounds: a process-based paradigmatic account. PhD Dissertation. University of Calgary.

von Heusinger, Klaus. \& Kornfilt, Jaklin. 2005. The case of the direct object in Turkish: Semantics, syntax and morphology. Turkic languages, 9, 3-44.

Jiménez-Fernández, Ángel. L. 2012. A new look at subject islands: The phasehood of definiteness. Anglica Wratislaviensia, 50, 137-168.

Massam, Diane. 2001. Pseudo noun incorporation in Niuean. Natural Language \& Linguistic Theory, 19(1), 153-197.

Öztürk, Balkız. et al. 2015. Possessive-free genitives in Turkish. Turcologica 103, 189-203. Harrassowitz.

Öztürk, Balk1z. \& Taylan, Eser. E. 2016. Possessive constructions in Turkish. Lingua, 182, 88108.

Roberts, Craige. 2003. Uniqueness in definite noun phrases. Linguistics and philosophy, 26(3), 287-350.

Russell, Bertrand. 1905. On Denoting. Mind (14).

Schwarz, Florian. 2009. Two types of definites in natural language. PhD Dissertation, UMASS. Travis, Lisa. 1988. The syntax of adverbs. McGill Working Papers in Linguistics, 20, 280-310. Zamparelli, Rob. 2014. Layers in the Determiner Phrase. London: Routledge. 